\title{
Single host and symbiont lineages of hydrothermal- vent gastropods Ifremeria nautilei (Provannidae): biogeography and evolution
}

\author{
Yohey Suzuki ${ }^{1, *}$, Shigeaki Kojima ${ }^{2}$, Hiromi Watanabe ${ }^{2}$, Masae Suzuki ${ }^{1}$, \\ Shinji Tsuchida ${ }^{1}$, Takuro Nunoura ${ }^{1}$, Hisako Hirayama ${ }^{1}$, Ken Takai $^{1}$, \\ Kenneth H. Nealson ${ }^{1,3}$, Koki Horikoshi ${ }^{1}$
}

${ }^{1}$ Extremobiosphere Research Center, Japan Agency for Marine-Earth Science \& Technology, 2-15 Natsushima-cho, Yokosuka, Kanagawa 237-0061, Japan

${ }^{2}$ Ocean Research Institute, The University of Tokyo, 1-15-1 Minamidai, Nakano, Tokyo 164-8639, Japan

${ }^{3}$ Department of Earth Sciences, University of Southern California, 3651 Trousdale Parkway, Los Angeles, California 90089-0740, USA

\begin{abstract}
Hydrothermal-vent gastropods belonging to the genus Ifremeria of the family Provannidae, which derive their nutrition from chemoautotrophic bacterial endosymbionts, constitute an important faunal element in the ecology of deep-sea hydrothermal systems in the SW Pacific. In order to determine phylogenetic relationships between the hosts and endosymbionts of Ifremeria gastropods, as well as their fatty-acid profiles and bulk and compound-specific carbon-isotopic signatures, we analyzed Ifremeria gastropods from the Manus, North Fiji and Lau Back-Arc Basins in the SW Pacific. Partial sequences of the mitochondrial cytochrome $c$ oxidase subunit I gene suggest that Ifremeria gastropods from the 3 basins belong to a single species, Ifremeria nautilei. Based on the $16 \mathrm{~S}$ rRNA gene sequences and results from fluorescence in situ hybridization analysis, the gill endosymbionts of Ifremeria gastropods from the 3 basins were grouped in a single lineage of $\gamma$-Proteobacteria, with sequence similarities of $>98.3 \%$. Placement of the endosymbionts within this single lineage was supported by fatty-acid profiles and carbon-isotopic compositions of the Ifremeria gastropods. Phylogenetic relationships inferred among gastropod hosts and among their endosymbionts were not congruent, implying that acquisition of endosymbionts might be from the environment rather than through vertical transmission. Differences in geographical distribution and host speciation pattern between the confamilial Alviniconcha and Ifremeria gastropods might be attributed to the remarkable differences in symbiotic strategy with chemoautotrophic bacteria.
\end{abstract}

KEY WORDS: Chemoautotrophic bacteria $\cdot$ Endosymbiosis $\cdot$ Provannidae $\cdot$ Gastropod

\section{INTRODUCTION}

Unlike hydrothermal-vent communities in the eastern Pacific, where large vestimentiferan tubeworms and bivalve mollusks are the most conspicuous organisms, the hydrothermal-vent sites in the SW Pacific are dominated by gastropods (Desbruyeres et al. 1994, Galkin 1997). In the Manus, North Fiji and Lau BackArc Basins, Alviniconcha and Ifremeria gastropods of the Provannidae family are the dominant primary consumers (Desbruyeres et al. 1994, Galkin 1997). For their nutrition, the 2 provannid gastropods are known to depend on the intracellular chemoautotrophic bacteria found in specialized cells called bacteriocytes in their gill filaments (Stein et al. 1988, Windoffer \& Giere 1997, Suzuki et al. 2005a,b, Urakawa et al. 2005). While the distribution of Ifremeria gastropods is restricted to the 3 SW Pacific basins (Waren \& Bouchet 
2001), Alviniconcha gastropods have a biogeographic distribution that extends from the 3 SW Pacific basins to the Central Indian Ridge of the Indian Ocean (Hashimoto et al. 2001) and the Mariana Trough in the western Pacific (Hessler \& Lonsdale 1991).

Previously, Ifremeria gastropods from the Manus and North Fiji Basins were grouped as a single species, Ifremeria nautilei (Kojima et al. 2000). Urakawa et al. (2005) reported phylogenetic affiliations of endosymbionts in I. nautilei from the Manus Basin. However, the host phylogenies of the Ifremeria gastropods from the Lau Basin and the phylogenies of the endosymbionts from the North Fiji and Lau Basins are currently unknown. We also reported that the Alviniconcha genus consists of 5 lineages (Kojima et al. 2001, 2004, Suzuki et al. 2006), each of which harbors phylogenetically distinct chemoautotrophic bacteria belonging to either the $\gamma$ - or the $\varepsilon$-Proteobacteria (Suzuki et al. 2005a,b, 2006, Urakawa et al. 2005). Given that Alviniconcha and Ifremeria gastropods employ similar nutritional strategies and inhabit similar hydrothermal vent habitats, Ifremeria gastropods may have established endosymbiotic relationships with diverse groups of chemoautotrophic bacteria. In the present study, we conducted a molecular survey of the host and endosymbiont lineages of Ifremeria gastropods from the 3 back-arc basins in the SW Pacific. We also conducted fatty acid profile and carbon-isotopic analyses of the gastropod tissues, in order to identify phenotypic traits and determine the carbon metabolism of the bacterial endosymbionts.

\section{MATERIALS AND METHODS}

Gastropod specimens. Gastropod specimens were collected from the 3 back-arc basins in the SW Pacific utilizing the manned submersibles 'Shinkai 2000' and 'Shinkai 6500'. The latitude/longitude and depth of the sampling site, the date of the sampling, and the submersible used for the sampling are summarized in Table 1. References for maps of the sampling locations are also listed in Table 1.
DNA analysis of mitochondrial cytochrome $c$ oxidase subunit I (COI) gene sequences. Total DNA was extracted from the head-food region of the specimens from the 3 back-arc basins by either (1) grinding, digestion with sodium dodecyl sulfate, and extraction with phenol and chloroform; or (2) by using the DNEasy kit (QIAGEN) and magnetically purifying using a MagExtractor kit (ТOYOBO), in accordance with the manufacturer's instructions. A fragment (about $960 \mathrm{bp}$ ) of the mitochondrial gene for COI was amplified by the polymerase chain reaction (PCR) with primers COI-B (Hasegawa et al. 1996) and COI-6 (Shimayama et al. 1990). The conditions for PCR were as follows: $94^{\circ} \mathrm{C}$ for $60 \mathrm{~s}$; and then 30 to 40 cycles at $92^{\circ} \mathrm{C}$ for $40 \mathrm{~s}, 50^{\circ} \mathrm{C}$ for $60 \mathrm{~s}$, and $72^{\circ} \mathrm{C}$ for $90 \mathrm{~s}$. The nucleotide sequence of the obtained fragment was determined using a sequencer (ABI3100 or ABI3130, Applied Biosystems) with the primer COI-3 (Shimayama et al. 1990), in addition to the PCR primers.

Phylogenetic relationships were estimated by the maximum-parsimony (MP) method, using a multiple, equally parsimonious heuristic search with tree bisection-reconnection and 1000 random addition sequence replicates, and by the maximum-likelihood (ML) method in the PAUP* package (Version 4.0b10) (Swofford 2002), and by the neighbor-joining (NJ) method (Saitoh \& Nei 1987) in MEGA 3 (Kumar et al. 2004). In addition, the 7 sequences obtained from the Ifremeria specimen, the endosymbiont of which was analyzed by Urakawa et al. (2005), were used for analysis. As an outgroup, the dominant haplotype of Alviniconcha hessleri from the Mariana Trough (Kojima et al. 2001; AB051791) was also used.

The mitochondrial COI gene sequences of Ifremeria gastropods from the Manus, North Fiji and Lau Basins are available from the DDBJ (DNA databank of Japan) under the accession numbers AB238951 to AB238957.

DNA analysis of endosymbiont 16S rRNA gene sequences. The endosymbiont DNA was extracted from the dissected gill tissues using the DNEasy kit and magnetically purified using MagExtractor, as described above. The endosymbiont 16S rRNA gene sequences were amplified by PCR using LA Taq poly-

Table 1. Ifremeria nautilei. Number of individuals studied in the SW Pacific (n), sample locations and depths, dates, dive numbers (submersible used) and references containing maps of the sample locations

\begin{tabular}{|c|c|c|c|c|c|c|c|}
\hline Species & $\mathrm{n}$ & Collection site & Location & Depth (m) & Date & Dive no. & Source \\
\hline I. nautilei & 3 & $\begin{array}{l}\text { STARMER II, } \\
\text { North Fiji Basin }\end{array}$ & $\begin{array}{l}16^{\circ} 59.3^{\prime} \mathrm{S} \\
173^{\circ} 55.0^{\prime} \mathrm{E}\end{array}$ & 1990 & 21 Oct 1991 & $\begin{array}{c}92 \\
\text { ('Shinkai 6500') }\end{array}$ & $\begin{array}{l}\text { Desbruyeres et al } \\
\text { (1994) }\end{array}$ \\
\hline I. nautilei & 3 & $\begin{array}{l}\text { PACMANUS, } \\
\text { Manus Basin, Field E }\end{array}$ & $\begin{array}{l}3^{\circ} 43.6^{\prime} \mathrm{S} \\
151^{\circ} 40.3^{\prime} \mathrm{E}\end{array}$ & 1676 & 2 Nov 1998 & $\begin{array}{c}1062 \\
\text { ('Shinkai 2000') }\end{array}$ & Galkin (1997) \\
\hline I. nautilei & 1 & $\begin{array}{l}\text { Vai Lili, } \\
\text { Lau Basin }\end{array}$ & $\begin{array}{l}22^{\circ} 12.9^{\prime} \mathrm{S} \\
176^{\circ} 36.5^{\prime} \mathrm{W}\end{array}$ & 1722 & 8 Oct 2004 & $\begin{array}{c}847 \\
\text { ('Shinkai 6500') }\end{array}$ & $\begin{array}{l}\text { Desbruyeres et al } \\
(1997)\end{array}$ \\
\hline
\end{tabular}


merase (TaKaRa) with the oligonucleotide primers Bac27F and Uni1492R (Lane 1991). Thermal cycling was performed using a GeneAmp 9700 thermal cycler, with 27 cycles of denaturation at $96^{\circ} \mathrm{C}$ for $20 \mathrm{~s}$, annealing at $53^{\circ} \mathrm{C}$ for $45 \mathrm{~s}$, and extension at $72^{\circ} \mathrm{C}$ for $120 \mathrm{~s}$. The amplified 16S rRNA gene-sequence products were cloned and then sequenced with an ABI 3100 capillary sequencer and a dRhodamine sequencing kit as per the manufacturer's recommendations (Perkin Elmer/Applied Biosystems). Bacterial clone libraries were constructed using the original TA cloning kit (Invitrogen).

The sequence similarity among all of the partial 16S rRNA gene sequences, which were 500 nucleotides long, was analyzed using the FASTA program with the DNASIS software (Hitachi Software). A single phylogenetic clone type (phylotype) was obtained from the clone-type analysis, and the partial sequence was extended and manually aligned according to the secondary structures using ARB (a software environment for sequence data; Ludwig et al. 2004). Phylogenetic analysis was performed by the NJ, MP, and ML methods using PAUP (Swofford 2002), based on 817 nucleotide positions (60 to 875, Escherichia coli numbering).

The bacterial 16S rRNA gene sequences from the gill endosymbionts of Ifremeria gastropods from the Manus, North Fiji, and Lau Basins are available from DDBJ under the accession numbers AB238958 to AB238964.

Fluorescence in situ hybridization (FISH) analysis. A previously designed rRNA-targeted oligonucleotide probe for the endosymbiont of Ifremeria nautilei from the Manus Basin was modified in the present study (Urakawa et al. 2005). The probe, hereafter referred to as Ifre576, is 17 bases long, which corresponds to Escherichia coli positions 576 to 592 (5'-GACTAAACCGCCTACGC-3'). For whole-cell hybridization, dissected gill filaments from 3 individuals were fixed in $4 \%$ paraformaldehyde in phosphate-buffered saline (PBS, pH 7.4) for $2 \mathrm{~h}$ and dehydrated in an ethanol series $(50,75$, and $100 \%, v / v)$, followed by 3 washes in xylene and infiltration with paraffin wax. The waxembedded specimens were then sectioned (thickness: $\sim 3 \mu \mathrm{m})$ and mounted on 3-aminopropyltriethyloxysilane (APTS)-coated slides. For the deparaffinized specimens, hybridization was conducted at $46^{\circ} \mathrm{C}$ in a solution containing $20 \mathrm{mM}$ Tris- $\mathrm{HCl}(\mathrm{pH} 7.4), 0.9 \mathrm{M}$ $\mathrm{NaCl}, 0.1 \%$ sodium dodecyl sulfate, $30 \%(\mathrm{v} / \mathrm{v})$ formamide, and $50 \mathrm{ng}^{-1}$ of the Ifre 576 probe and the 'universal' bacterial probe EUB338 (Giovannoni et al. 1988), which were labeled at the 5 '-end with Cy-3 and fluorescein, respectively. After hybridization, the slide was washed at $48^{\circ} \mathrm{C}$ in a solution lacking the probe and formamide at the same stringency, adjusted by $\mathrm{NaCl}$ concentration (Lathe 1985), and subsequently stained with 4',6-diamidino-2-phenylindole (DAPI) at $0.4 \mathrm{\mu g} \mathrm{ml}^{-1}$. The slides were examined using either an Olympus BX51 microscope or an Olympus FV5000 confocal laser-scanning microscope. A negative control probe for Ifre576, in which 2-base mismatches were introduced in the middle (5'-GACTAATCCTCCTACGC-3'), was used for testing unspecific labeling.

Bulk carbon-isotopic analysis. Gastropod individuals were dissected into gill and mantle tissues, and the dissected tissues were lyophilized. A small portion of each lyophilized tissue was powdered and then acidfumed for $6 \mathrm{~h}$ (Van Dover 2002). The rest of the untreated lyophilized tissue was stored at $-80^{\circ} \mathrm{C}$ for fatty-acid extraction. The carbon-isotopic compositions of the cultures and the gastropod tissues were analyzed by a Thermo Electron DELTA ${ }^{\text {plus }}$ Advantage mass spectrometer connected to an elemental analyzer (EA1112) through a ConFlo III interface. The measured isotopic composition was expressed as $\delta^{13} \mathrm{C}$, which can be defined as follows:

$$
\delta^{13} \mathrm{C}=\left[\left({ }^{13} \mathrm{C} /{ }^{12} \mathrm{C}\right)_{\text {sample }} /\left({ }^{13} \mathrm{C} /{ }^{12} \mathrm{C}\right)_{\text {standard }}-1\right] \times 10^{3}
$$

where $\left({ }^{13} \mathrm{C} /{ }^{12} \mathrm{C}\right)_{\text {sample }}$ is the ${ }^{13} \mathrm{C} /{ }^{12} \mathrm{C}$ abundance ratio for the sample and $\left({ }^{13} \mathrm{C} /{ }^{12} \mathrm{C}\right)_{\text {standard }}$ is the ${ }^{13} \mathrm{C} /{ }^{12} \mathrm{C}$ abundance ratio for the Pee Dee Belemnite carbonate (PDB) standard. The values of $\delta^{13} \mathrm{C}$ therefore represent the difference, in parts per thousand (per mille, \%), between the ${ }^{13} \mathrm{C} /{ }^{12} \mathrm{C}$ value of the sample and that of the standard.

Analysis of the fatty-acid methyl-ester (FAME) profiles. For the extraction of cellular fatty acids (FA), a method described in Komagata \& Suzuki (1987) was used. Approximately $20 \mathrm{mg}$ of gastropod tissue was incubated in $1 \mathrm{ml}$ of anhydrous methanolic hydrochloric acid at $100^{\circ} \mathrm{C}$ for $3 \mathrm{~h}$. After the addition of $1 \mathrm{ml}$ of deionized, distilled water (DDW) to the cooled aliquots, FAMEs were extracted 3 times with $3 \mathrm{ml}$ of $\mathrm{n}$-hexane. The $\mathrm{n}$-hexane fractions were washed with an equal volume of DDW and dehydrated with anhydrous $\mathrm{Na}_{2} \mathrm{SO}_{4}$. The concentrated FAMEs were stored at $-20^{\circ} \mathrm{C}$ for subsequent carbon-isotopic analyses. Although this extraction method degrades the cyclopropyl FAME (Moss et al. 1974), it enables minimum loss of material during extraction.

The identities of the FAMEs were determined by comparison of the retention times and spectra to those of known FAME standards by gas chromatographymass spectrometry (GC-MS), using a Shimadzu GCQ GC-MS system. The oven temperature was set to $140^{\circ} \mathrm{C}$ for $3 \mathrm{~min}$ and then increased to $250^{\circ} \mathrm{C}$ at a rate of $4^{\circ} \mathrm{C}$ $\mathrm{min}^{-1}$, with $\mathrm{He}$ at a constant flow of $1.1 \mathrm{ml} \mathrm{\textrm {min } ^ { - 1 }}$ through a DB-5MS column $(30 \mathrm{~m} \times 0.25 \mu \mathrm{m} \times 0.25 \mathrm{~mm}$; J\&W Scientific). The double-bond positions of the monounsaturated FAMEs were determined by analyzing their dimethyl disulfide adducts (Nichols et al. 
1986). The standard nomenclature for FA was used. FAs are designated $X: Y \Delta Z$, where $X$ is the number of carbon atoms, $Y$ is the number of double bonds, and $Z$ is the position of the double bond from the carboxyl end.

Compound-specific carbon-isotopic analysis. The $\delta^{13} \mathrm{C}$ values of the FAMEs were determined by the GCcarbon-isotope ratio MS using a Thermo Electron DELTA $^{\text {plus }}$ Advantage mass spectrometer connected to a GC (Agilent 6890) through a GC/C/C/III interface. The oven temperature was set to $120^{\circ} \mathrm{C}$ for $3 \mathrm{~min}$ and then increased to $300^{\circ} \mathrm{C}$ at a rate of $4^{\circ} \mathrm{C} \mathrm{min}{ }^{-1}$, with $\mathrm{He}$ at a constant flow of $1.1 \mathrm{ml} \mathrm{min}{ }^{-1}$ through a HP-5 column (30 $\mathrm{m} \times 0.25 \mu \mathrm{m} \times 0.25 \mathrm{~mm}$; Agilent). The isotopic compositions of the FAMEs were measured with an internal isotopic standard $\left(19: 0, \delta^{13} \mathrm{C}=-29.80 \%\right.$ ), and the additional carbon atom from the methanolderivatizing reagent $\left(\delta^{13} \mathrm{C}=-39.04 \%\right.$ o) was corrected. The measurement errors produced by the internal isotopic standard were within $1 \%$ for all isotopic analyses.

\section{RESULTS}

\section{Phylogenetic analysis of Ifremeria gastropods}

Partial nucleotide sequences (771 base pairs) of the mitochondrial COI gene were obtained from a single specimen from the Lau Basin and 3 specimens from the Manus and North Fiji Basins. All determined sequences formed a clear monophyletic cluster with the Ifremeria nautilei sequences determined by Kojima et al. (2000) (data not shown). Therefore, the sequence similarity among the Ifremeria gastropods from the 3 SW Pacific basins suggests that they are all affiliated to the single species $I$. nautilei.
Phylogenetic analysis revealed that the Ifremeria gastropods from 3 basins were divided into 2 clades, namely those from the Manus Basin group and those from the 2 remaining basins (Fig. 1). The monophyly of the latter was supported by high bootstrap value (96/94/91 for NJ/MP/ML methods, respectively), and a sequence of a single specimen from the Lau Basin was identical to 2 of those from the North Fiji Basin. On the other hand, the monophyly of the former was supported by relatively low bootstrap values (66/75/65 for NJ/MP/ML), and additional phylogenetic analyses that included previously analyzed haplotypes suggested that the Manus Basin group is paraphyletic (data not shown).

\section{Phylogenetic analyses of Ifremeria endosymbionts}

The phylogenetic relationships among gill endosymbionts, the host lineages of which were analyzed as described above, were determined based on 16S rRNA gene sequences. Examination of the 8 clones generated from the 16S rRNA gene-sequence library from the gill filaments of each gastropod showed only 1 phylotype. Phylogenetic analysis placed the phylotypes within the $\gamma$-Proteobacteria (Fig. 2). The $\gamma$-proteobacterial phylotypes of the Ifremeria gastropods are closely related to a previously described endosymbiont of I. nautilei from the Manus Basin, and share sequence similarities of $>98.3 \%$ (Urakawa et al. 2005). The closest relative of the $\gamma$-proteobacterial phylotypes of the Ifremeria endosymbionts was the endosymbiont harbored in Alviniconcha hessleri from the Mariana Trough in the western Pacific (Suzuki et al. 2005a).

In order to ensure that the phylotypes revealed by 16S rRNA gene-sequence clone-library analysis were

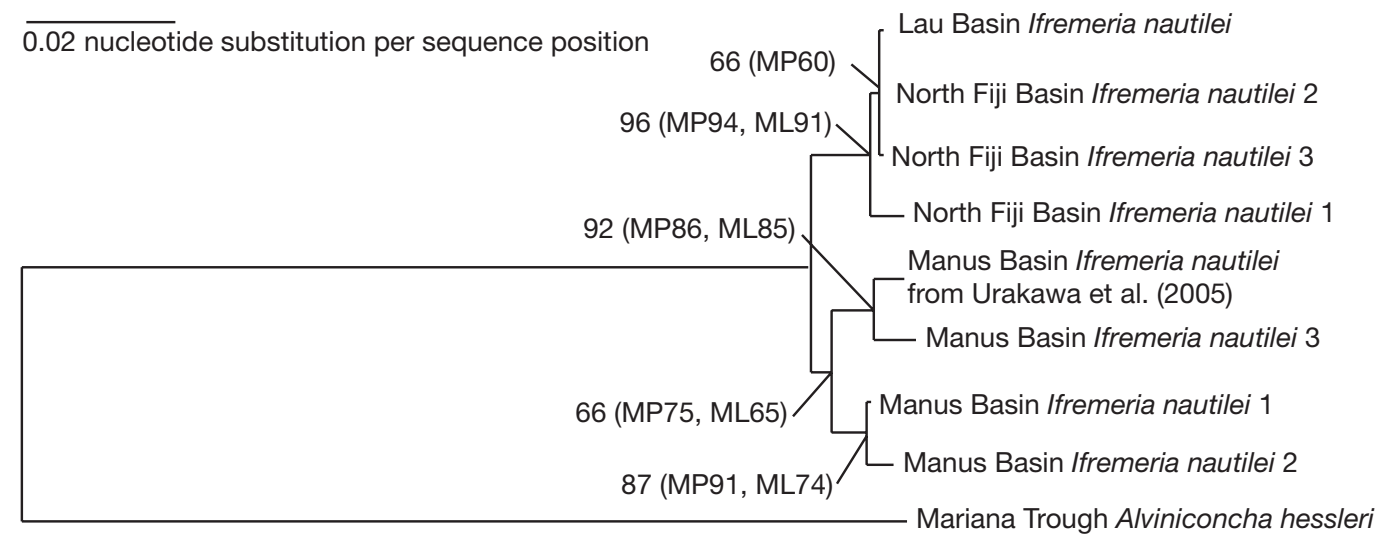

Fig. 1. Phylogenetic relationships among Ifremeria gastropods from the SW Pacific. The tree was constructed using the neighborjoining method, with Alviniconcha hessleri from the Mariana Trough as an outgroup. Bootstrap probabilities based on 1000 replicates are shown for branches with $>50 \%$ bootstrap support. The phylogenetic relationships were also analyzed using the maximum-parsimony (MP) and the maximum-likelihood (ML) methods. Bootstrap probabilities based on 1000 replicates using the MP and ML methods are shown in parentheses for branches with $>50 \%$ bootstrap support 


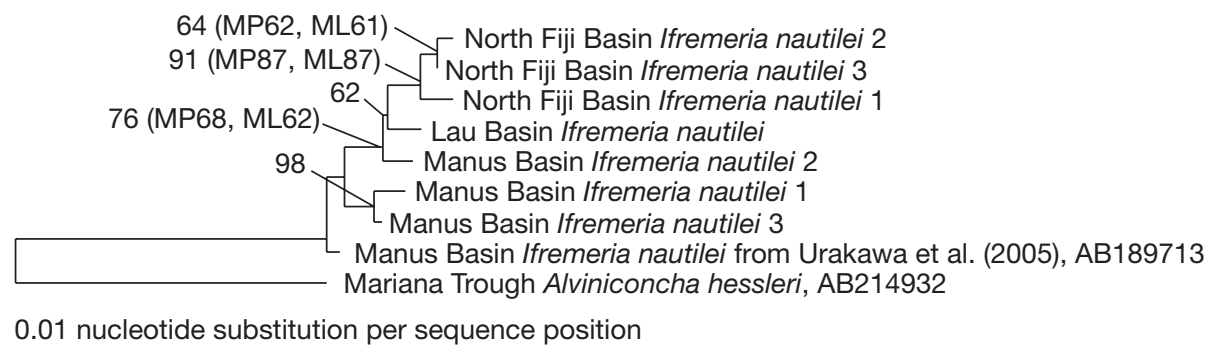

Fig. 2. Phylogenetic relationships among the endosymbionts of Ifremeria gastropods from the SW Pacific. The tree was constructed using the neighbor-joining method, with Alviniconcha hessleri from the Mariana Trough as an outgroup. Bootstrap values were analyzed and are shown as described in Fig. 1

only those of the endosymbionts in the gill filaments, we conducted FISH analysis using the probe Ifre576 for all Ifremeria gastropod specimens examined in the present study. The sections of the gill filaments were hybridized with the EUB338 and Ifre576 probes, followed by DNA staining with DAPI. Representative epifluorescence micrographs of the gill filaments of the Ifremeria gastropod from the Lau Basin are shown in Fig. 3. The presence of dense aggregates of bacterial cells, as well as host nuclei (labeled ' $N$ ' in Fig. 3A,D), in

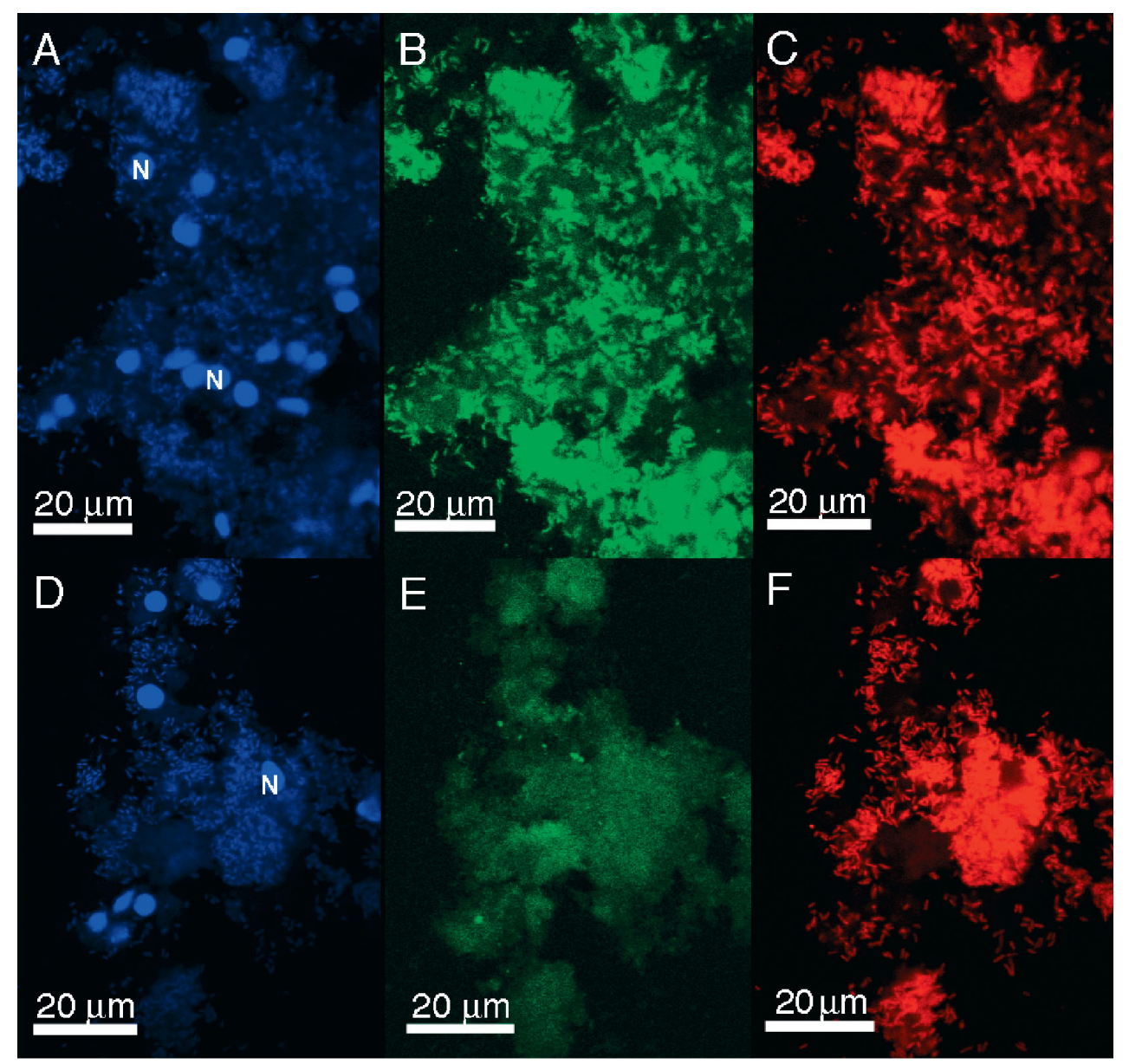

Fig. 3. Epifluorescence micrographs of the endosymbiotic bacteria associated with the gill filaments of Ifremeria nautilei from the Lau Back-Arc Basin. (A) DNA staining of the section of the gill filaments with 4', 6-diamidino-2-phenylindole (DAPI). In addition to the bacterium-like cells, the host nuclei are stained and labeled 'N.' (B) Fluorescence in situ hybridization (FISH) performed with the fluorescein-labeled Ifre576 probe (same microscopic field as that of Panel A). (C) FISH performed with the Cy-3-labeled EUB338 probe. (D) DNA staining of the section of the gill filaments with DAPI. (E) FISH performed with the fluorescein-labeled Ifre576 probe in which 2-base mismatches were introduced (same microscopic field as that of Panel D). (F) FISH performed with the Cy-3-labeled EUB338 probe 
the gill filaments was confirmed by FISH analysis with the EUB338 probe and DAPI staining (Fig. 3A,C,D,F). Hybridization with the Ifre576 probe specific for the $\gamma$-proteobacterial phylotype gave a signal pattern almost identical to that of the EUB338 probe (Fig. 3B,C), indicating that most of the endosymbiotic bacterial cells are affiliated to the phylotype. A negative control probe, in which 2-base mismatches were introduced in the middle of the Ifre576 probe, did not hybridize with the bacterial cells under the same conditions used for FISH analysis with the mismatch-free Ifre576 probe, indicating the absence of nonspecific labeling (Fig. 3E,F).

\section{Bulk carbon-isotopic analysis}

The $\delta^{13} \mathrm{C}$ values of the gastropod gill and mantle tissues were measured. The gastropod tissues had a $\delta^{13} \mathrm{C}$ range from -28.2 to $-33.9 \%$, as shown in Table 2. Despite the abundance of endosymbiont cells in the gill, the carbon-isotopic composition of the symbiont-free mantle tissue was nearly identical to that of gill tissue, indicating that the endosymbiont biomass was as ${ }^{13} \mathrm{C}$-depleted as the symbiont-free gastropod tissue.

\section{FAME profiles}

The analysis of the FAME profiles from the gastropod tissues showed high levels of saturated $\mathrm{C}_{16}$ and $\mathrm{C}_{18}$ fatty acids and of the monounsaturated fatty acids
$16: 1 \Delta 9,18: 1 \Delta 11$, and $20: 1 \Delta 13$ (Fig. 4). In addition, the monosaturated fatty acid $16: 1 \Delta 8$ was particularly abundant in the gill tissue.

\section{Compound-specific carbon-isotopic analysis}

The carbon-isotopic compositions of several FAMEs from the gastropod tissues were measured; the ${ }^{13} \mathrm{C}$ values of the FAMEs after correction for the methanolderivatizing reagent and the total FAMEs calculated on the basis of the FAME compositions are shown in Table 2 . The FAMEs analyzed in this study were all ${ }^{13} \mathrm{C}$ depleted relative to the gastropod biomass, by 4.4 to $12.5 \%$.

\section{DISCUSSION}

\section{Single host and endosymbiont lineages}

Although the host lineages of Alviniconcha gastropods are diverse (Kojima et al. 2001, 2004, Suzuki et al. 2006), Ifremeria gastropods from the 3 back-arc basins in the SW Pacific are closely related and all affiliated to the single species I. nautilei (Kojima et al. 2000).

Ifremeria gastropods examined to date by $16 \mathrm{~S}$ rRNA gene sequence analysis all harbor chemoautotrophic endosymbionts that phylogenetically fall into the single lineage of the $\gamma$-Proteobacteria. The monounsaturated $C_{16}$ fatty acids $16: 1 \Delta 8$ and $16: 1 \Delta 9$ are thought to originate mostly from the $\gamma$-proteobacterial endosymbionts, given that they were abundant in the

Table 2. Ifremeria nautilei, Alviniconcha spp. Carbon-isotopic compositions of the total biomass and fatty-acid methyl-esters (FAME) of gastropods harboring $\gamma$-proteobacterial endosymbionts. Carbon-isotopic compositions are reported as $\delta^{13} \mathrm{C}$ values $(\%) ;$ data are means $\left( \pm\right.$ SD) $\left(\right.$ ND: not determined). ${ }^{*}$ Suzuki et al. $(2006){ }_{i}{ }^{* *}$ Suzuki et al. $(2005 a)$

\begin{tabular}{|c|c|c|c|c|c|c|c|}
\hline $\begin{array}{l}\text { Species } \\
\text { (Collection Site) }\end{array}$ & $\begin{array}{l}\text { Host } \\
\text { tissue }\end{array}$ & $\begin{array}{c}\text { Total } \\
\text { biomass }\end{array}$ & $16: 1$ & $16: 0$ & $\begin{array}{l}\text { FAME } \\
18: 1\end{array}$ & $18: 0$ & $20: 2$ \\
\hline $\begin{array}{l}\text { I. nautilei } \\
\text { (PACMANUS, Manus Basin, Field E) }\end{array}$ & $\begin{array}{l}\text { Gill } \\
\text { Mantle }\end{array}$ & $\begin{array}{l}-33.8 \pm 0.7 \\
-33.9 \pm 2.5\end{array}$ & $\begin{array}{l}-40.8 \pm 0.9 \\
-40.8 \pm 0.8\end{array}$ & $\begin{array}{l}-41.4 \pm 1.0 \\
-40.2 \pm 0.3\end{array}$ & $\begin{array}{l}-41.0 \pm 0.2 \\
-40.9 \pm 0.1\end{array}$ & $\begin{array}{l}-39.3 \pm 0.5 \\
-39.5 \pm 0.1\end{array}$ & $\begin{array}{l}-39.9 \pm 1.1 \\
-39.6 \pm 0.1\end{array}$ \\
\hline $\begin{array}{l}\text { I. nautilei } \\
\text { (STARMER II site, North Fiji Basin) }\end{array}$ & $\begin{array}{l}\text { Gill } \\
\text { Mantle }\end{array}$ & $\begin{array}{l}-32.2 \pm 1.3 \\
-30.9 \pm 1.3\end{array}$ & $\begin{array}{l}-36.9 \pm 1.3 \\
\text { ND }\end{array}$ & $\begin{array}{l}-38.4 \pm 0.7 \\
-38.4 \pm 0.5\end{array}$ & $\begin{array}{l}-37.8 \pm 0.3 \\
-37.2 \pm 0.6\end{array}$ & $\begin{array}{l}-36.6 \pm 0.1 \\
-36.3 \pm 0.6\end{array}$ & $\begin{array}{l}-36.5 \pm 0.9 \\
-37.3 \pm 0.1\end{array}$ \\
\hline $\begin{array}{l}\text { I. nautilei } \\
\text { (Vai Lili site, Lau Basin) }\end{array}$ & $\begin{array}{c}\text { Gill } \\
\text { Mantle }\end{array}$ & $\begin{array}{l}-28.5 \\
-28.2\end{array}$ & $\begin{array}{l}-39.6 \\
\mathrm{ND}\end{array}$ & $\begin{array}{l}-41.0 \\
-36.7\end{array}$ & $\begin{array}{l}-39.9 \\
-36.1\end{array}$ & $\begin{array}{l}-40.0 \\
-36.0\end{array}$ & $\begin{array}{l}-38.9 \\
-35.6\end{array}$ \\
\hline $\begin{array}{l}\text { Alviniconcha sp. Type } 1 \\
\text { (White Lady site, North Fiji Basin)* }^{*}\end{array}$ & Gill & $-30.7 \pm 0.6$ & $-38.4 \pm 0.8$ & $-38.2 \pm 0.7$ & $-37.4 \pm 0.4$ & $-36.9 \pm 0.1$ & $-37.0 \pm 0.4$ \\
\hline $\begin{array}{l}\text { Alviniconcha sp. Type } 1 \\
\text { (PACMANUS, Manus Basin, Field D)* }^{*}\end{array}$ & $\begin{array}{l}\text { Gill } \\
\text { Mantle }\end{array}$ & $\begin{array}{l}-30.5 \pm 0.3 \\
-30.0 \pm 0.1\end{array}$ & $\begin{array}{l}-37.5 \pm 1.0 \\
-36.7 \pm 0.4\end{array}$ & $\begin{array}{l}-38.0 \pm 0.7 \\
-37.1 \pm 0.2\end{array}$ & $\begin{array}{l}-36.6 \pm 0.9 \\
-37.6 \pm 0.1\end{array}$ & $\begin{array}{r}36.6 \pm 0.0 \\
-36.9 \pm 0.3\end{array}$ & $\begin{array}{l}-36.8 \pm 0.6 \\
-37.3 \pm 0.1\end{array}$ \\
\hline $\begin{array}{l}\text { Alviniconcha sp. } \\
\text { (Vai Lili site, Lau Basin)* }^{*}\end{array}$ & $\begin{array}{l}\text { Gill } \\
\text { Mantle }\end{array}$ & $\begin{array}{l}-30.5 \\
-30.0\end{array}$ & $\begin{array}{l}-36.1 \\
-35.6\end{array}$ & $\begin{array}{l}-36.8 \\
-36.3\end{array}$ & $\begin{array}{l}-36.1 \\
-36.1\end{array}$ & $\begin{array}{l}-35.8 \\
-36.0\end{array}$ & $\begin{array}{l}-36.0 \\
-35.7\end{array}$ \\
\hline $\begin{array}{l}\text { Alviniconcha hessleri } \\
\text { (Alice Springs, Mariana Trough)** }^{*}\end{array}$ & $\begin{array}{l}\text { Gill } \\
\text { Mantle }\end{array}$ & $\begin{array}{l}-29.7 \pm 0.4 \\
-28.4 \pm 0.5\end{array}$ & $\begin{array}{l}-38.6 \pm 0.9 \\
-36.1 \pm 0.4\end{array}$ & $\begin{array}{l}-39.5 \pm 0.6 \\
-36.8 \pm 0.1\end{array}$ & $\begin{array}{l}-37.7 \pm 0.5 \\
-36.4 \pm 0.5\end{array}$ & $\begin{array}{r}36.5 \pm 0.7 \\
-35.7 \pm 0.4\end{array}$ & $\begin{array}{l}-36.9 \pm 0.4 \\
-36.5 \pm 0.9\end{array}$ \\
\hline
\end{tabular}



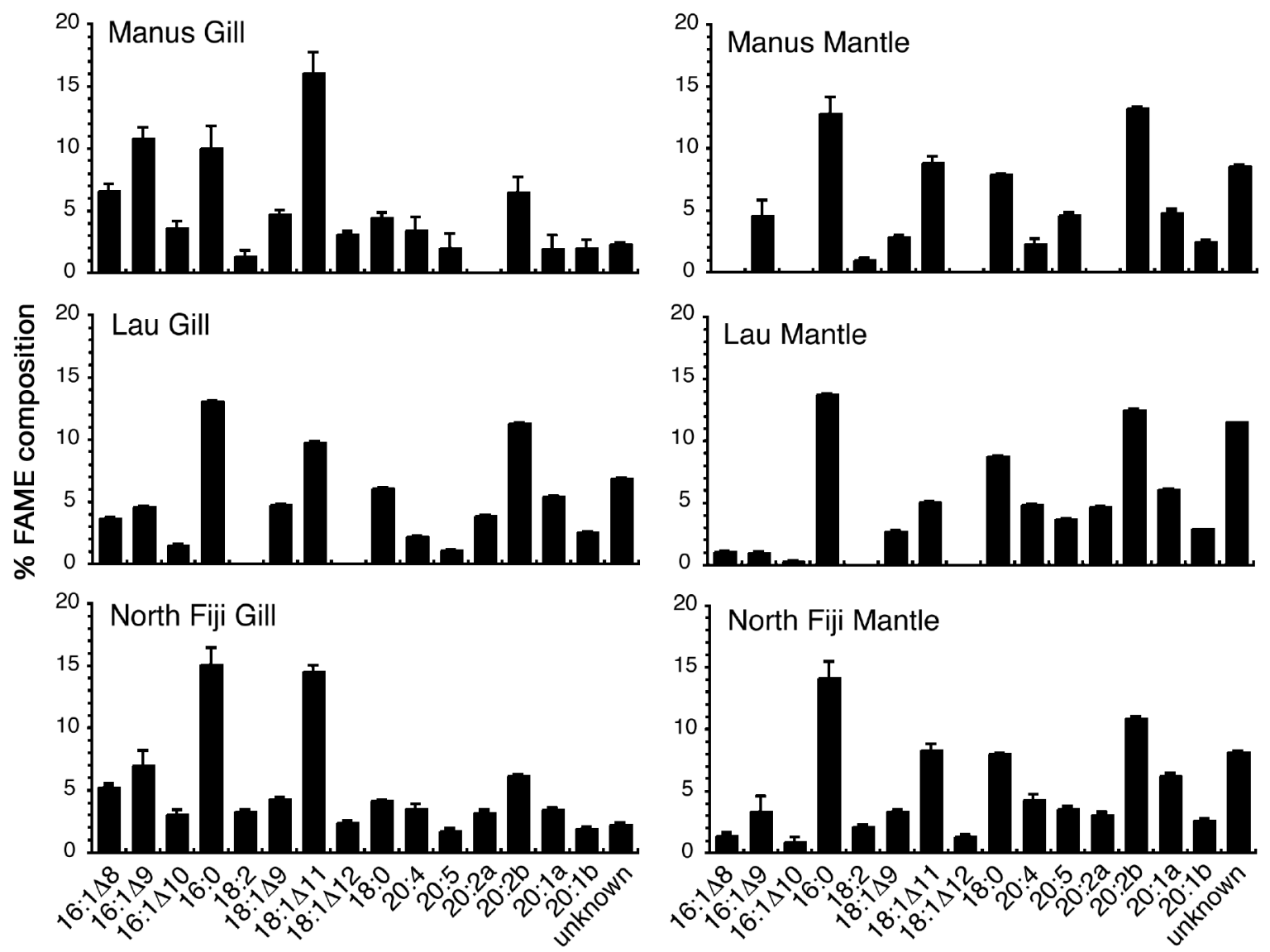

Fig. 4. Ifremeria nautilei. Fatty-acid profiles of the gill and mantle tissues from Ifremeria gastropods from the 3 SW Pacific back-arc basins. Values are means (+SD) of at least 2 parallel measurements of tissues (gill and mantle) from each of the 3 individuals

symbiont-bearing gill tissue. These fatty acids were abundant in the gill tissues of all Ifremeria gastropods examined in the present study, as well as in specimens previously sampled from the White Lady site in the North Fiji Basin (Pranal et al. 1996).

The carbon-isotopic compositions of the gastropod tissues, as well as the carbon isotope fractionation patterns of the fatty acids relative to whole-gastropod tissues, were similar among Ifremeria gastropods from the 3 basins and Alviniconcha gastropods that depend upon $\gamma$-proteobacterial endosymbionts for nutrition (Table 2). Previous enzymatic analysis has shown that the endosymbionts of Ifremeria gastropods from the North Fiji and Lau Basins mediate the Calvin-Benson cycle for $\mathrm{CO}_{2}$ fixation (Desbruyeres et al. 1994). The carbon-isotopic compositions of the Ifremeria gastropods examined in the present study are consistent with the chemoautotrophy of the Calvin-Benson cycle. These polyphasic results indicate that Ifremeria gastropods are nutritionally dependent upon chemoautotrophic endosymbionts within the single lineage of the $\gamma$-Proteobacteria.

\section{Host-symbiont relationships in Ifremeria gastropods}

Phylogenetic relationships among hosts and their symbionts have provided fundamental insights into the evolutionary histories of deep-sea hydrothermal vent fauna and their endosymbionts, as well as the modes of symbiont acquisition (Distel 1998, Peek et al. 1998, DiMeo et al. 2000, Won et al. 2003). Although the endosymbiont of the Ifremeria gastropod from the Lau Basin grouped separately from the endosymbiont taxa from the North Fiji Basin, the gastropod host from the Lau Basin clustered with those from the North Fiji Basin. Similarly, Ifremeria hosts and endosymbionts from the Manus Basin previously examined by Urakawa et al. (2005), as well as the Ifremeria specimens examined in the present study, exhibited phylogenetic relationships that were incongruent with each other. This lack of congruence between host and endosymbiont phylogenies may have resulted from the absence of coevolution of Ifremeria gastropods and their endosymbionts through horizontal transmission of the symbionts from one generation to the next. However, the phylogenetic incongruence might be 
ascribed to polymorphic populations of the gastropods with respect to the genotype of symbionts.

\section{Dispersal capabilities of the 2 provannid gastropods}

Vent animals with planktonic larval stages tend to have considerable dispersal capabilities (Van Dover et al. 2002). Based on larval and egg capsule observations in Alviniconcha gastropods, it appears that Alviniconcha gastropods undergo planktonic development (Waren \& Bouchet 1993), whereas the modes of development in Ifremeria gastropods are currently unknown. Kojima et al. (2000) implied that the difference in the dispersal potential of the 2 provannid gastropods might be attributed to the non-planktonic development of Ifremeria gastropods.

Bathymodiolus mussels, which are able to form dual endosymbioses with sulfur-oxidizing chemoautotrophic and methanotrophic bacteria (Fisher 1990), are almost ubiquitous in deep-sea hydrothermal-vent and cold-seep environments, while most other bivalve hosts harbor a single lineage of sulfur-oxidizing chemoautotrophic endosymbionts (Distel et al. 1994). Won et al. (2003) speculated that the global distribution of Bathymodiolus mussels is related to this capacity for dual endosymbioses. In the present study, it was determined that in sharp contrast to Alviniconcha gastropods, which have endosymbiotic relationships with chemoautotrophic bacteria in 6 lineages of both $\gamma$ - and $\varepsilon$-Proteobacteria (Suzuki et al. 2006), the endosymbionts of Ifremeria gastropods belonged to a single lineage of $\gamma$-Proteobacteria. Taken together, the endosymbiont diversities of provannid gastropods might be correlated with their dispersal capabilities.

\section{Host evolution possibly affected by chemoautotrophic endosymbiosis}

Alviniconcha spp. and Ifremeria nautilei thrive in the hydrothermal-vent habitats in the SW Pacific. Although Alviniconcha gastropods have diversified to a great extent and have established mutualistic endosymbioses with a wide variety of chemoautotrophic bacteria, Ifremeria gastropods have endosymbiont relationships that are restricted to 1 group of the Proteobacteria. While the mechanisms employed by both gastropods for maintaining or changing their endosymbiotic relationships remain unclear, the congruence between the host and endosymbiont diversities might support the inference that the evolution of the 2 hydrothermal-vent-endemic gastropods has been profoundly influenced by their endosymbiotic associations with chemoautotrophic bacteria.
Acknowledgements. We thank the captains and crews of the RV 'Yokosuka' and 'Natsushima' and the operators of the 'Shinkai 2000' and 'Shinkai 6500' for their technical expertise. We also thank T. Sasaki and Y. Kano for their contributions.

\section{LITERATURE CITED}

Desbruyeres D, Alayse AM, Ohta S (1994) Deep-sea hydrothermal communities in southwestern Pacific back-arc basins (the North Fiji and Lau Basins): composition, microdistribution and food web. Mar Geol 116:227-242

DiMeo CA, Wilbur AE, Holben WE, Feldman RA, Vrijenhoek RC, Cary SC (2000) Genetic variation among endosymbionts of widely distributed vestimentiferan tubeworms. Appl Environ Microbiol 66:651-658

Distel DL (1998) Evolution of chemoautotrophic endosymbioses in bivalves. BioScience 48:277-286

Distel DL, Felbeck H, Cavanaugh CM (1994) Evidence for phylogenetic congruence among sulfur-oxidizing chemoautotrophic bacterial endosymbionts and their bivalve hosts. J Mol Evol 38:533-542

Fisher CR (1990) Chemoautotrophic and methanotrophic symbioses in marine invertebrates. Rev Aquat Sci 2: 399-436

Galkin SV (1997) Megafauna associated with hydrothermal vents in the Manus Back-Arc Basin. Mar Geol 142: 197-206

Giovannoni SJ, DeLong EF, Olsen GJ, Pace NR (1988) Phylogenetic group-specific oligodeoxynucleotide probes for identification of single microbial cells. J Bacteriol 170: $720-726$

Hasegawa T, Yamaguchi T, Kojima S, Ohta S (1996) Phylogenetic analysis among three species of intertidal barnacles of the genus Tetraclita (Cirripedia: Balanomorpha) by nucleotide sequences of a mitochondrial gene. Benthos Res 51:33-39 (in Japanese with English abstract)

Hashimoto J, Ohta S, Chiba H, Yamaguchi T and 5 others (2001) First hydrothermal vent communities from the Indian Ocean discovered. Zool Sci 18:717-721

Hessler RR, Lonsdale P (1991) Biogeography of Mariana Trough hydrothermal vent communities. Deep-Sea Res 38:185-199

Kojima S, Segawa R, Fujiwara Y, Hashimoto J, Ohta S (2000) Genetic differentiation of populations of a hydrothermal vent-endemic gastropod, Ifremeria nautilei, between the North Fiji Basin and the Manus Basin revealed by nucleotide sequences of mitochondrial DNA. Zool Sci 17: $1167-1174$

Kojima S, Segawa R, Fujiwara Y, Fujikura K, Ohta S, Hashimoto J (2001) Phylogeny of hydrothermal-vent-endemic gastropods Alviniconcha spp. from the western Pacific revealed by mitochondrial DNA sequences. Biol Bull (Woods Hole) 200:298-304

Kojima S, Fujikura K, Okutani T, Hashimoto J (2004) Phylogenetic relationship of Alviniconcha gastropods from the Indian Ocean to those from the Pacific Ocean (Provannidae: Mollusca) revealed by nucleotide sequences of mitochondrial DNA. Venus 63:65-68

Komagata K, Suzuki K (1987) Lipid and cell wall analysis in bacterial systematics. Methods Microbiol 19:161-207

Kumar S, Tamura K, Nei M (2004) MEGA3: integrated software for molecular evolutionary genetics analysis and sequence alignment briefings. Bioinformatics 5:150-163

Lane DJ (1991) 16S/23S rRNA sequencing. In: Stackebrandt E, Goodfellow $M$ (eds) Nucleic acid techniques in bacterial systematics. John Wiley \& Sons, New York, p 115-175 
Lathe R (1985) Synthetic oligonucleotide probes deduced from amino acid sequence data. Theoretical and practical considerations. J Mol Biol 183:1-12

Ludwig W, Strunk O, Westram R, Richter L and 28 others (2004) ARB: a software environment for sequence data. Nucleic Acids Res 32:1363-1371

Moss CW, Lambert MA, Merwin W (1974) Comparison of rapid methods for analysis of bacterial fatty acids. Appl Microbiol 28:80-85

Nichols PD, Guckert JB, White DC (1986) Determination of monounsaturated fatty acid double-bond position and geometry for microbial monocultures and complex consortia by capillary GC-MS of their dimethyl disulphide adducts. J Microbiol Methods 5:49-55

Peek AS, Feldman RA, Lutz RA, Vrijenhoek RC (1998) Cospeciation of chemoautotrophic bacteria and deep sea clams. Proc Natl Acad Sci USA 95:9962-9966

Pranal V, Fiala Medioni A, Guezennec J (1996) Fatty acid characteristics in two symbiotic gastropods from a deep hydrothermal vent of the West Pacific. Mar Ecol Prog Ser 142:175-184

Saitoh N, Nei M (1987) The neighbour-joining method: a new method for reconstructing phylogenetic trees. Mol Biol Evol 10:471-483

Shimayama T, Himeno H, Sasuga J, Yokobori S, Ueda T, Watanabe K (1990) The genetic code of a squid mitochondrial gene. Nucleic Acids Symp Ser 22:77-78

Stein JL, Cary SC, Hessler RR, Ohta S, Vetter RD, Childress JJ, Felbeck H (1988) Chemoautotrophic symbiosis in a hydrothermal vent gastropod. Biol Bull (Woods Hole) 174: 373-378

Suzuki Y, Sasaki T, Suzuki M, Nealson KH, Horikoshi K (2005a) Molecular phylogenetic and isotopic evidence of two lineages of chemoautotrophic endosymbionts distinct at the subdivision level harbored in one host-animal type: the genus Alviniconcha (Gastropoda: Provannidae). FEMS Microbiol Lett 249:105-112

Editorial responsibility: Otto Kinne (Editor-in-Chief), Oldendorf/Luhe, Germany
Suzuki Y, Sasaki T, Suzuki M, Nogi Y, Miwa T, Takai K, Nealson KH, Horikoshi K (2005b) Novel chemoautotrophic endosymbiosis between a member of the $\varepsilon$-Proteobacteria and the hydrothermal-vent gastropod Alviniconcha aff. hessleri (Gastropoda: Provannidae) from the Indian Ocean. Appl Environ Microbiol 71:5440-5450

Suzuki Y, Kojima S, Sasaki T, Suzuki M and 9 others (2006) Host-symbiont relationships in hydrothermal gastropods of the genus Alviniconcha from the Southwest Pacific. Appl Environ Microbiol 72:1388-1393

Swofford DL (2002) PAUP*: phylogenetic analysis using parsimony ( ${ }^{*}$ and other methods), Version $4.0 \mathrm{~b} 10$. Sinauer Associates, Sunderland, MA

Urakawa H, Dubilier N, Fujiwara Y, Cunningham DE, Kojima S, Stahl DA (2005) Hydrothermal vent gastropods from the same family (Provannidae) harbour $\varepsilon$ - and $\gamma$-proteobacterial endosymbionts. Environ Microbiol 7:750-755

Van Dover CL (2002) Trophic relationships among invertebrates at the Kairei hydrothermal vent field (Central Indian Ridge). Mar Biol 141:761-772

Van Dover CL, German CR, Speer KG, Parson LM, Vrijenhoek RC (2002) Evolution and biogeography of deep-sea vent and seep invertebrates. Science 295:1253-1257

Waren A, Bouchet P (1993) New records, species, genera, and a new family of gastropods from hydrothermal and hydrocarbon seeps. Zool Scr 22:1-90

Waren A, Bouchet P (2001) Gastropoda and Monoplacophora from hydrothermal vents and seeps; new taxa and records. Veliger 44:116-231

Windoffer R, Giere O (1997) Symbiosis of the hydrothermal vent gastropod Ifremeria nautilei (Provaninidae) with endobacteria-structural analyses and ecological considerations. Biol Bull (Woods Hole) 193:381-392

Won Y, Hallam SJ, O'Mullan GD, Pan IL, Buck KR, Vrijenhoek RC (2003) Environmental acquisition of thioautotrophic endosymbionts by deep-sea mussels of the genus Bathymodiolus. Appl Environ Microbiol 69:6785-6792

Submitted: August 4, 2005; Accepted: October 27, 2005 Proofs received from author(s): April 14, 2006 